\title{
Tradicionalne in molekularne metode za determinacijo ščitkarjev (Aleyrodidae)
}

\author{
Maja DOBRAJC ${ }^{1}$, Sebastjan RADIŠEK ${ }^{1}$, Jernej JAKŠE ${ }^{2}$, Stanislav TRDAN ${ }^{2,3}$
}

Received November 04, 2020; accepted December 01, 2020. Delo je prispelo 04. novembra 2020, sprejeto 01. decembra 2020.

Tradicionalne in molekularne metode za determinacijo ščitkarjev (Aleyrodidae)

Izvleček: Ščitkarji (Aleyrodidae) so vrstno manj pestra skupina žuželk, ki obsega okoli 1500 vrst iz 160 rodov. Zaradi prehranjevanja $z$ rastlinskimi sokovi so pomembni škodljivci kmetijskih in okrasnih rastlinskih vrst, kjer povzročajo neposredno in posredno škodo. Večina vrst izvira iz tropskih območij, pri nas pa so najpogostejši v rastlinjakih. Z vse pogostejšim vnosom ščitkarjev na nova območja in njihovih invazivnim delovanjem, je determinacija teh žuželk pomemben sestavni del varstva rastlin. Identifikacija ščitkarjev v stadiju odraslega osebka je zahtevna in problematična. Za morfološko determinacijo in taksonomsko določitev je primerna le razvojna stopnja puparija, zato so določevalni ključi redki in pomanjkljivi. Oblika puparija je odvisna od gostiteljskih rastlin in abiotskih vplivov, zato sta nabiranje in nadaljnja determinacija pogosto težavni. Razvoj modernih metod determinacije in genetska diagnostika je omogočila natančnejšo determinacijo, preučitev filogenetskih povezav med vrstami ščitkarjev in pripravo načrtov za biotično zatiranje teh škodljivcev. Najpogosteje se v modernem pristopu determinacije ščitkarjev uporabljajo računalniški programi za analizo fotografije, molekularne metode izolacije DNA in sekvenciranje.

Ključne besede: morfološka determinacija; mtCOI; programska oprema proposed sistem; ščitkarji; škodljivci
Traditional and molecular methods for the identification of whitefly (Aleyrodidae) species

Abstract: Whiteflies (Aleyrodidae) is small group of insects (Insecta) that comprises around 1500 species from 160 genera. Whiteflies damage important cultivated and ornamental plants by sucking plants juice. Most of the species are from tropical area, in our region they are the most common in greenhouses. Because worldwide transport, whiteflies become invasive all around the world. The identification of whiteflies species in adult stage is problematic. Morphological differentiation of pupae is one of the better methods for determining identity of species, but it may vary depending on the host plant on which they develop which can lead to misidentifications and erroneous naming of new species. The application of genetic diagnostics under the umbrella of classical taxonomy was imperative for successful development and delivery of the biological control program, phylogenetics and plans for biological control. The most common modern techniques for whiteflies determination are computer programs for photography analysis, molecular methods with DNA isolation and sequencing.

Key words: morphological determination; $m t C O I$; proposed system; whitefly; pests

1 Inštitut za hmeljarstvo in pivovarstvo Slovenije, Žalec

2 Univerza v Ljubljani, Biotehniška fakulteta, Oddelek za agronomijo, Ljubljana, Slovenija

3 Korespondenčni avtor, e-naslov: stanislav.trdan@bf.uni-lj.si 


\section{UVOD}

Ščitkarje (Aleyrodidae) (slika 1) uvrščamo v podred prsokljuncev (Sternorrhyncha), red polkrilcev (Hemiptera) in razred žuželk (Insecta). Družina ščitkarjev (Aleyrodidae) obsega dve poddružini. Poddružina Aleurodicinae je endemična na območju centralne in južne Amerike in je glede na kompleksno zgradbo žilnega sistema kril taksonomsko primitivna. Zapletena zgradba žilnega sistema kril je lahko posledica velikosti predstavnikov poddružine Aleurodicinae (večji od $2 \mathrm{~mm}$ ), saj so le-ti precej večji od poddružine Aleyrodinae. Poddružina Aleyrodinae je globalno razširjena in ima večje število vrst (Byrne in Bellows Jr., 1991). Do danes je v svetu opisanih več kot 1500 vrst ščitkarjev (Hodges in Evans, 2005), ki jih uvrščamo v 161 rodov. Odrasli osebki so veliki $2-3 \mathrm{~mm}$ in spominjajo na manjše molje, saj imajo zaradi voščenega poprha telo bele barve. Okončine so dobro razvite. Na glavi so členjene antene s sedmimi členi in ustni aparat za sesanje in bodenje (Perring in sod., 2018). Nimfe in odrasli osebki imajo pogosto vzorce različnih oblik, ki so strokovnjakom $\mathrm{v}$ pomoč pri determinaciji vrst (Botha in sod., 2000).

Ščitkarji se razmnožujejo spolno, le redko tudi partenogenetsko. Samice jajčeca oddajo na površje različnih rastlinskih organov, pogosto na spodnjo stran listov, nekatere samice predstavnikov poddružine Aleurodicinae pa odlagajo jajčeca tudi na plodove in zgornjo ali spodnjo stran listov. Jajčeca odložijo $\mathrm{v}$ polpravilnem ali pravilnem krogu, saj so medtem prisesane na stalno mesto. Ličinke prve stopnje so mobilne, gibljejo se na krajše razdalje. $\mathrm{Na}$ trajno mesto se prisesajo po prvi levitvi, ki ga do tretje stopnje ne zapustijo. Zadnja stopnja ličink so pupariji; na njihovi morfološki zgradbi je temeljila sistematika celotne družine (Gill, 1990). Ščitkarji so polifagni ali oligofagni. Prehranjujejo se s sesanjem floemskega soka, pri čemer bodalo vstavijo $\mathrm{v}$ tkivo rastlin. Zadržujejo se na toplih in vlažnih prostorih. Številne vrste so gospodarsko pomembne (Milevoj, 2003).

Ščitkarji so pomembni škodljivci, saj imajo na kmetijske rastlinske vrste neposredni in posredni vpliv. Med hranjenjem $\mathrm{z}$ rastlinskimi sokovi vbrizgavajo $\mathrm{v}$ zdrave rastline številne toksine (Watson, 2007), ki povzročijo venenje, slabšo rast in odmiranje rastlin (Botha in sod., 2000). Nimfe povzročijo fiziološke spremembe vegetativnih delov, kot so nepravilno zorenje plodov in sivenje listov (Hoddle, 2004). Nekatere vrste ščitkarjev so tudi vektorji prenosa gospodarsko pomembnih virusov ( $\mathrm{Tr}-$ dan, 2015). Medena rosa ščitkarjev je medij gliv sajavosti (Capnodium spp.) (Byrne in Bellows Jr., 1991). Največjo gospodarsko škodo in izgubo pridelka povzročata tobakov ščitkar (Bemisia tabaci [Gennadius, 1889]) in rastlinjakov ščitkar (Trialeudores vaporariorum Westwood, 1856). V Sloveniji se na kapusnicah pogosto pojavlja in posredno povzroča škodo tudi kapusov ščitkar (Aleyrodes proletella [Linnaeus, 1758]) (Trdan in sod., 2003). Na območju Evrope ščitkarji povzročajo škodo na zelenjadnicah in okrasnih rastlinah, gojenih $\mathrm{v}$ rastlinjakih, kjer lahko povzročijo tudi do $50 \%$ uničenja rastlin. So tudi škodljivci citrusov, različnih drugih sadnih dreves in grmov (Šimala in sod., 2015).

Sistematika poddružin ščitkarjev temelji na morfološki determinaciji četrte stopnje nimfe, imenovane puparij (Martin in sod., 2000). Za puparij je značilna fenotipska plastičnost, kot odgovor na zgradbo lista rastline in abiotskih dejavnikov okolja (Guershon in Gerling,

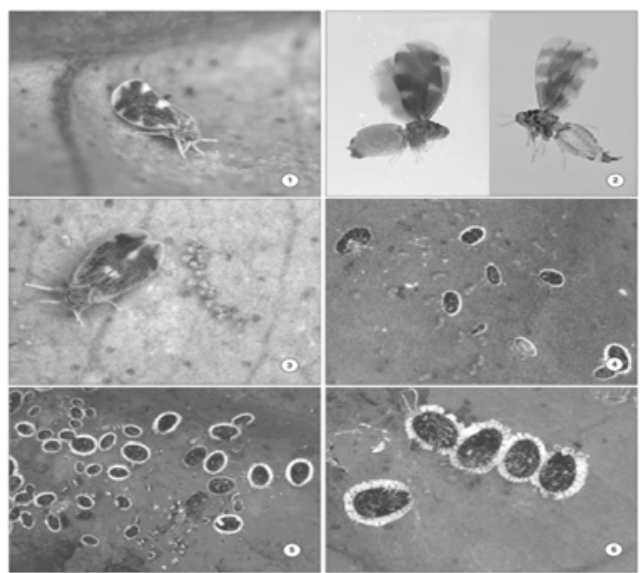

Slika 1: 1-Ščitkar Aleurocanthus spiniferus; 2-levo odrasla samica, desno odrasel samec; 3-ovalna, ledvičasto oblikovana jajčeca; 4-jajčeca in mlade nimfe v 1. in 2. stopnji; 5-odrasle nimfe v 3. in 4. stopnji; 6-pupariji (Radonjić in sod., 2014).

Figure 1: 1-Aleurocanthus spiniferus; 2-female left, male right; 3-elongate-oval to kidney-shaped eggs; 4-eggs and young nymphs 1st and 2nd instars; 5-lder nymphs 3rd and 4th instars and sooty mould; 6-4th instars - puparia (Radonjić in sod., 2014). 
2001). Zato je determinacija pogosto otežena. Morfološka determinacija odraslih osebkov je mogoča le za poddružino Aleurodicinae, saj določevalni ključi za ostali poddružini še niso enotni in $\mathrm{v}$ uporabi (Ghahari in sod., 2009). Moderne molekularne tehnike omogočajo natančnejšo determinacijo vrst ščitkarjev (Oliveira in sod., 2000; Calvert in sod., 2001; Shatters in sod., 2009). Za filogenetske povezave in determinacijo se uporablja mitohondrijska DNK (mDNK), saj pojasnjuje polimorfizem med bližnjimi vrstami (Brown in sod., 1979; Lunt in sod., 1996). Akumulacija sprememb nukleotidov in polimorfizem vplivata na izgube ali dodajanja restrikcijskih mest, brez bistvene spremembe v velikosti genoma (Hebert in sod., 2003). Spremembe znotraj mitohondrijskega gena citokrom oksidaze I (COI), so primeren kazalnik za uporabo DNK barkodiranega sistema determinacije na ravni določanja vrst (Hebert in sod., 2003; Kress in Erickson, 2008). Osnova molekularnega pristopa določanja ščitkarjev so specifični PCR začetni oligonukleotidi, ki se prilegajo COI genu, njegovo pomnoževanje in razrez z restrikcijskimi encimi (polimorfizem dolžin restrikcijskih fragmentov) (Vidigal in sod., 2002; Caldeira in sod., 2003; Thyssen in sod., 2005). Znane COI sekvence (preko 150 000) so zbrane v GenBank in The Barcode of Life Data System (BOLD) zbirkah ter so temelj za taksonomijo in filogenijo žuželk (Kwong in sod., 2012; Ptaszynska in sod., 2012; Smith in sod., 2012).

\section{MORFOLOŠKA IDENTIFIKACIJA}

Odrasli osebki ščitkarjev iz družine Aleyrodidae so podobni manjšim moljem, zato so jih $\mathrm{v}$ prvih morfoloških študijah mnogokrat zamenjevali s pritlikavimi listnimi zavrtači (Nepticulidae). Jajčeca so na spodnji strani listov gostiteljih rastlin na dolgih ali kratkih pecljih. Površje jajčec je pogosto gladko ali v obliki satovja. Številne vrste ležejo jajčeca v polkrožnih ali krožnih vrstah. Larvalne stopnje so štiri, pogosto je četrta larvalna stopnja puparij. Prva larvalna stopnja ima dobro razvite okončine in antene, je blede do prosojne barve in edina mobilna larvalna stopnja, ki lahko izbere stalno mesto za razvoj nadaljnjih larvalnih stopenj. Pri številnih vrstah je za puparij značilno izločanje voskastih sekretov iz papil ali enostavnih oziroma sestavljenih por. Odrasli osebek zapusti zadnjo larvalno stopnjo na območju zadka iz odprtine $\mathrm{v}$ obliki črke $\mathrm{T}$.

Pri mnogih vrstah se odrasli osebki začnejo prehranjevati takoj po izleganju, še pred aktivacijo kril. Oba spola odraslih osebkov imata dva para membranskih kril brez prečnih žil. Spolni dimorfizem se kaže le na območju razlik v genitalijah, številu ventralnih abdominalnih voščenih ploščic, anten in manjšemu telesu samcev. Ne- katere vrste imajo več kot en rod letno. Morfološka determinacija poteka s preučevanjem juvenilnih osebkov $\mathrm{v}$ različnih stopnjah razvoja pod mikroskopom. Determinacija specifičnih značilnosti je vezana na število, velikost in lokacijo por, odprtin, papil ter set (Perring in sod., 1993).

Identifikacija se začne z zbiranjem osebkov iz listov gostiteljskih rastlin s pomočjo lupe. Liste rastlin je potrebno posušiti in shraniti do njihove preparacije. Identifikacija in klasifikacija zbranih žuželk na ravni vrste se določi na podlagi morfoloških lastnosti odraslih žuželk in ličink, pri čemer so v uporabi klasične identifikacijske metode, kot so morfološki ključi. Ličinke in puparije ščitkarjev se določi z mikroskopiranjem v kanadskem balzamu po prilagojenih metodah Wilkey (1962) ali Watson in Chandler (1999). Standardizirani postopek po Wilkey (1962) je sledeč: vzorce potopimo v $10 \%$ kalijev hidroksid (KOH), kjer jih lahko shranjujemo od 12 do 24 ur. Nato jih vzamemo iz $\mathrm{KOH}$ in jih za $10-15$ min potopimo $\mathrm{v}$ destilirano vodo. $\mathrm{V}$ destilirano vodo dodamo eno ali dve kapljici kontrastnega barvila. Vzorce pustimo v raztopini $15 \mathrm{~min}$. Osebke nato vzamemo iz barvila in jih potopimo v $75 \%$ etanol (EtOH) za $10 \mathrm{~min}$, kar razbarva vse nesklerotizirane regije. Osebke iz $75 \% \mathrm{EtOH}$ prenesemo v $95 \%$ etanol (EtOH) za 10-15 min. Vzorce potopimo v olje nageljnovih žbic za $30 \mathrm{~min}$ ali več. Na objektno stekelce nanesemo kanadski balzam in vanj položimo vzorec, ki ga označimo in pokrijemo z drugim objektnim stekelcem. Vzorce sušimo v sušilni napravi tri tedne pri $35{ }^{\circ} \mathrm{C}$ (Hodges in Evans, 2005). Za identifikacijo so v uporabi določevalni ključi Takahashi (1952; 1954), Mound (1966), Habib in Farag (1970), Martin (1985; 1978; 1999), Bink-Moenen in Gerling (1990), Mifsud (1995) in Martin in sod. (2000). Natančna identifikacija se izvaja s stereomikroskopom in svetlobnim mikroskopom.

\section{MODERNE TEHNIKE IDENTIFIKACIJE ŠČITKARJEV}

\subsection{PROGRAMSKA OPREMA PROPOSED SISTEM}

Za identifikacijo bolezni in škodljivcev na rastlinah in njihovih škodljivcev so $\mathrm{v}$ uporabi številni moderni pristopi zaznavanja, prepoznavanja in taksonomskega uvrščanja posameznih vrst. $\mathrm{Z}$ razvojem tehnologije in računalniških sistemov, so se razvili tudi programi za prepoznavanje škodljivcev in obdelavo velike količine podatkov. Računalniški program, imenovan Proposed system, je programska oprema za detekcijo in klasifikacijo bolezenskih znamenj na listih rastlin ali rastlinskih škodljivcev. Shema programske opreme sestoji iz štirih ključnih korakov. Prvi korak je izdelava barvne strukture 


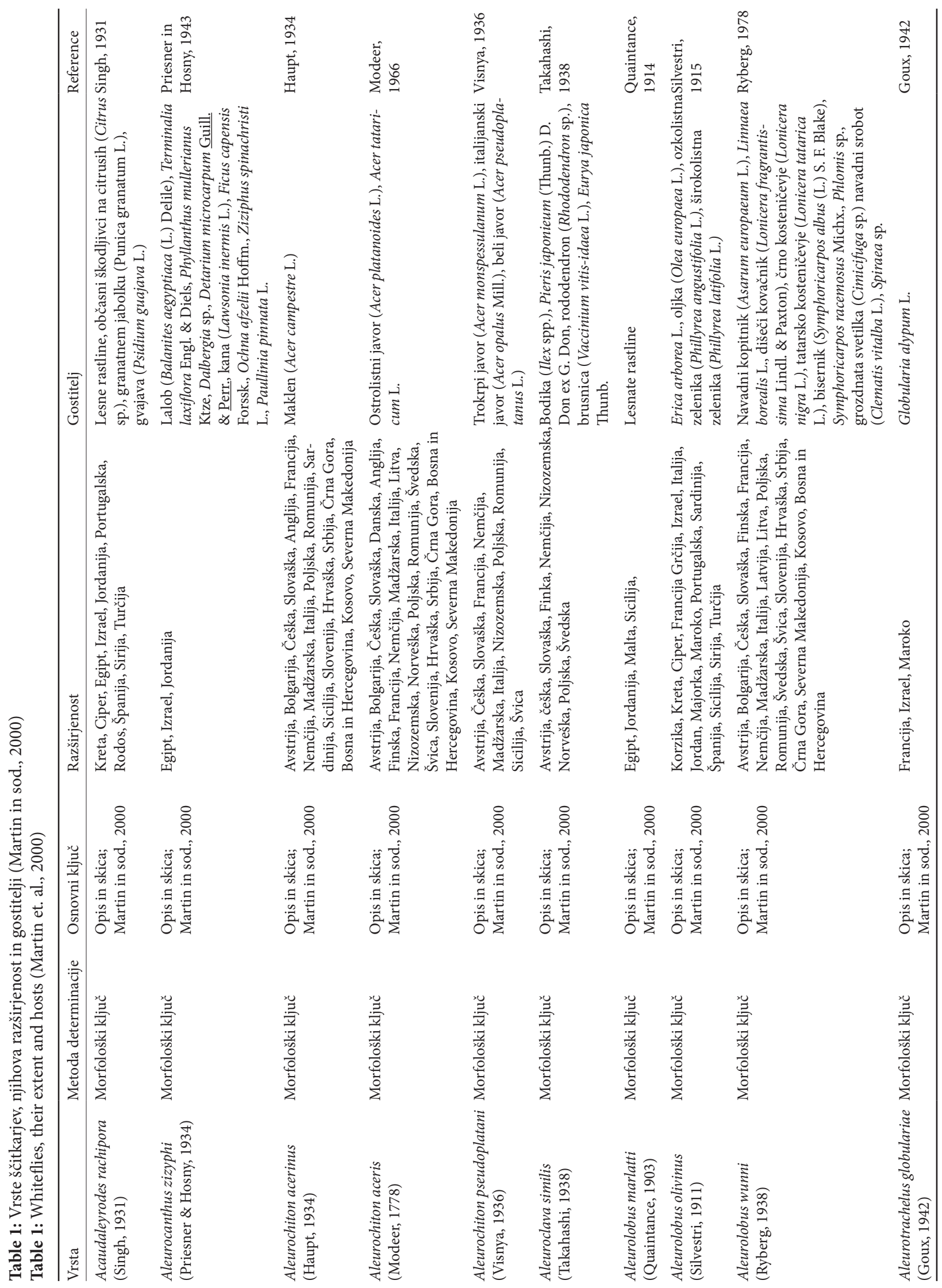




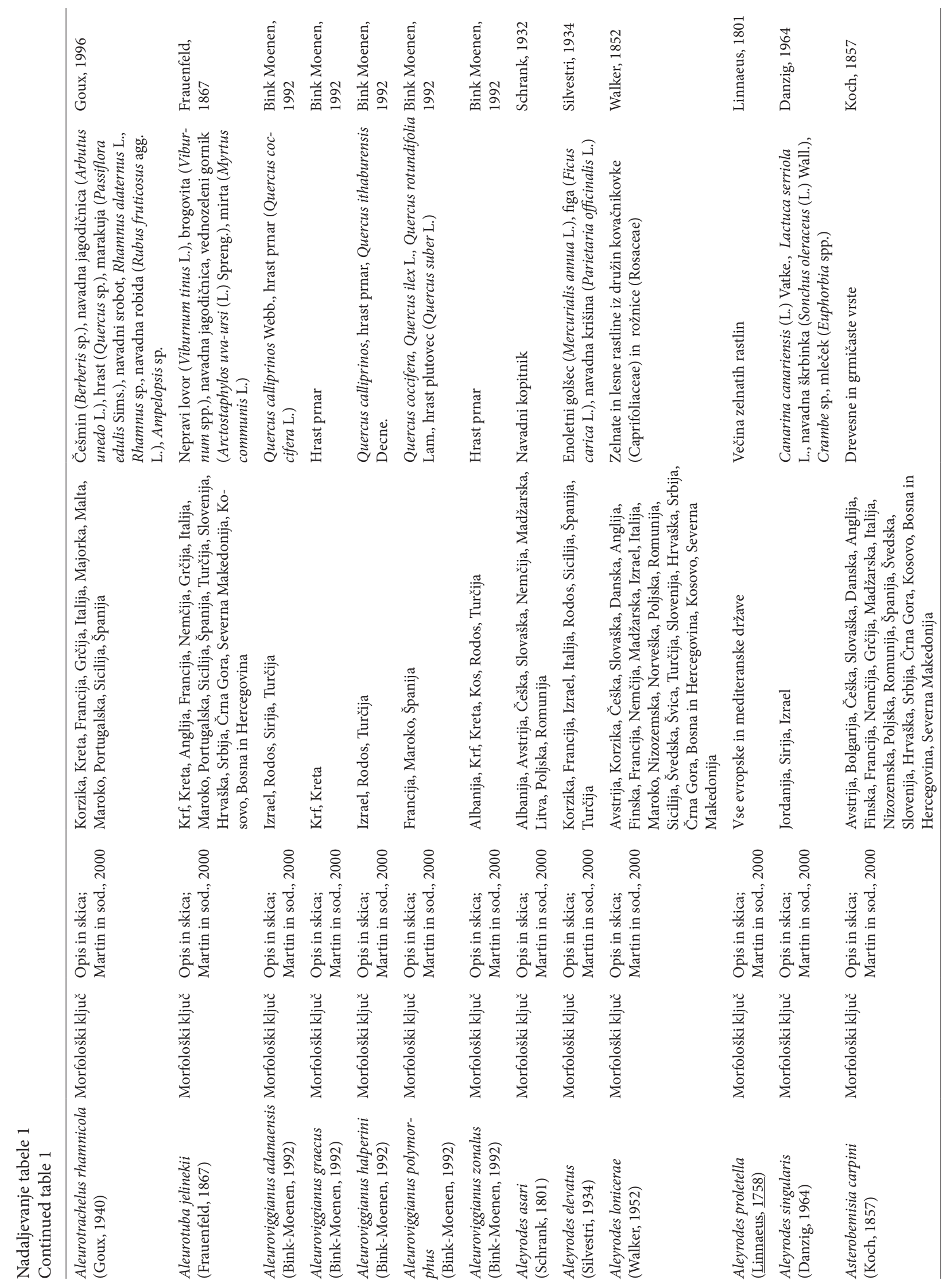




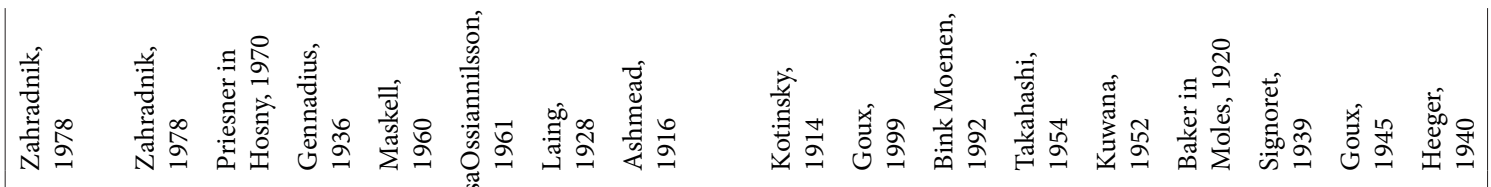

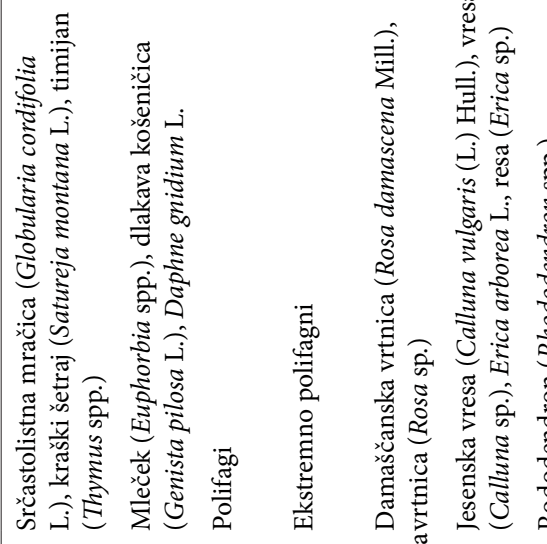

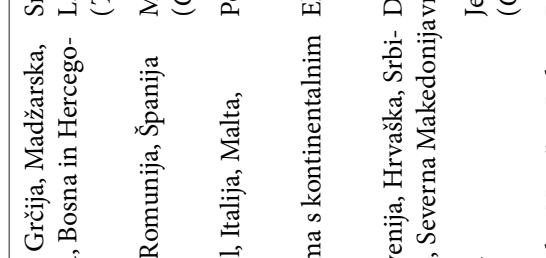

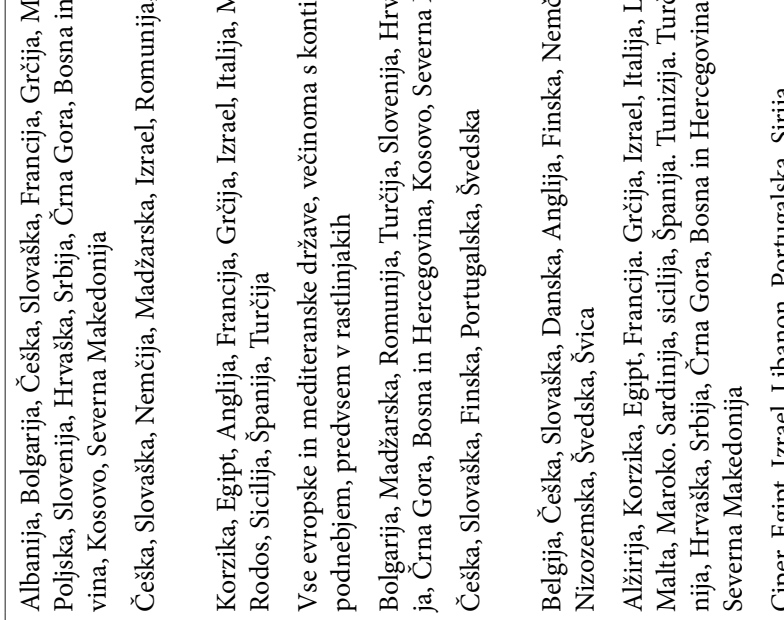

ว

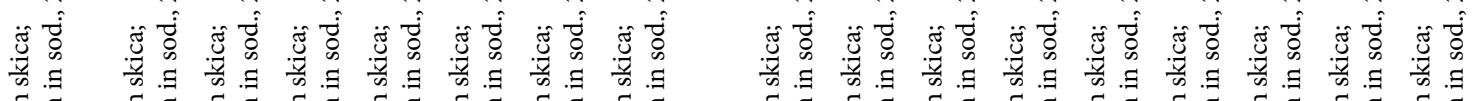

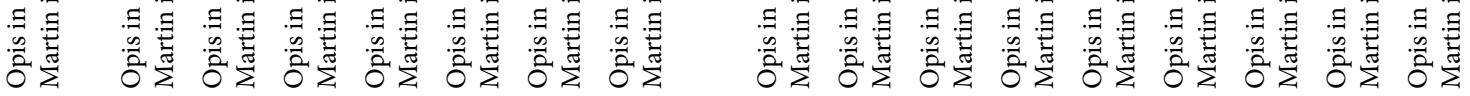

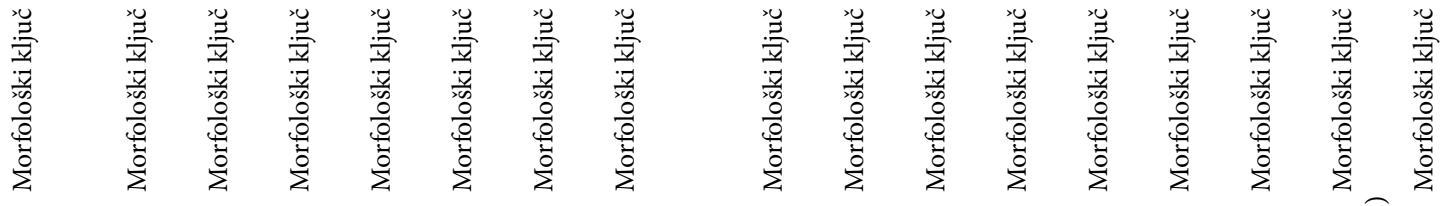

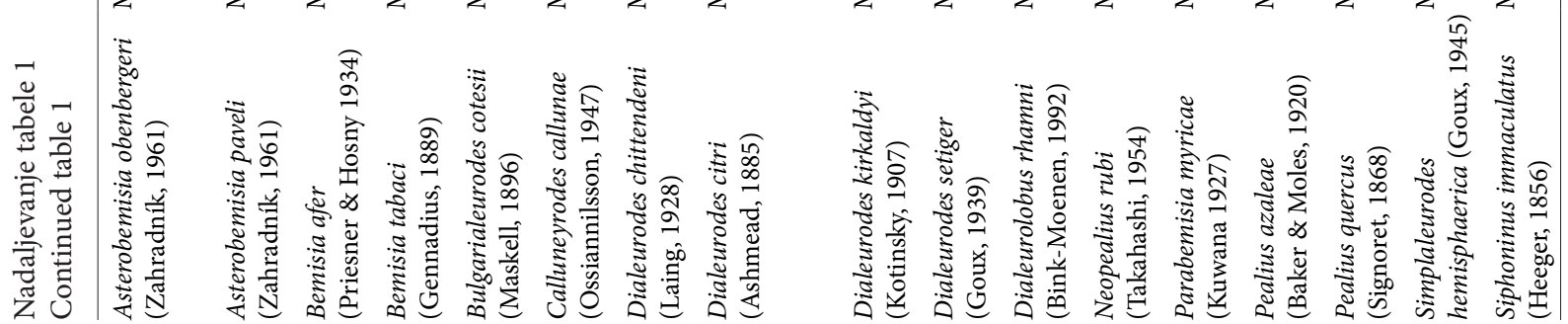




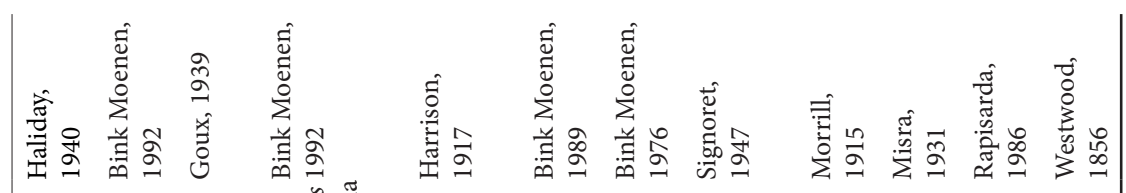

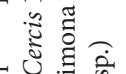

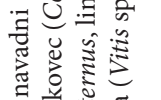

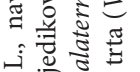

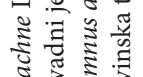

密

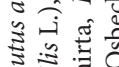

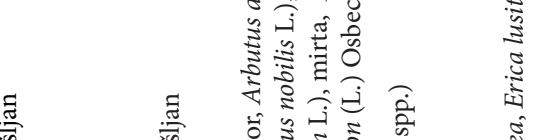

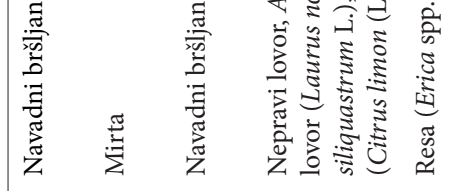

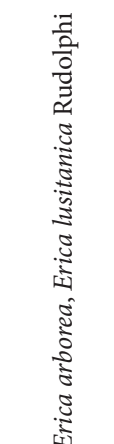

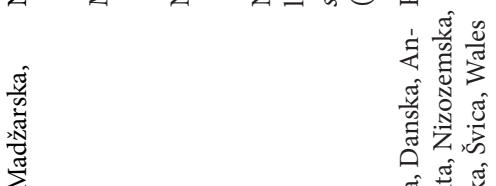

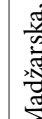

(1)

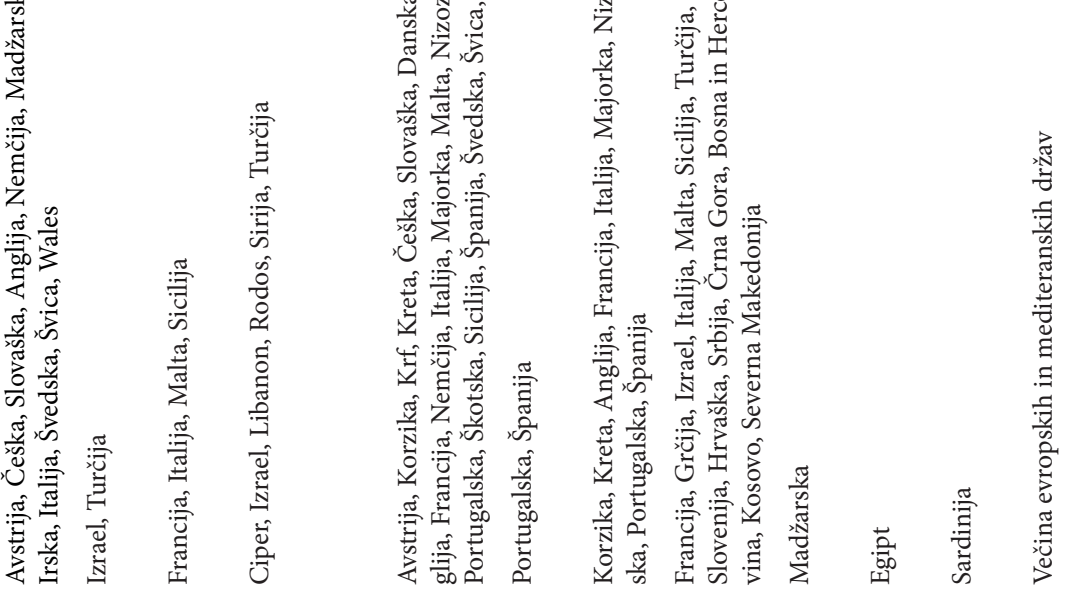

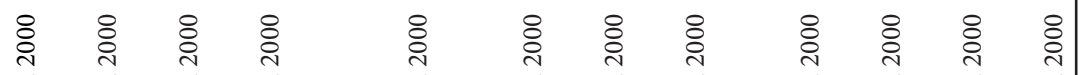

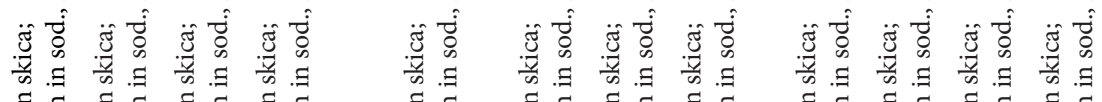

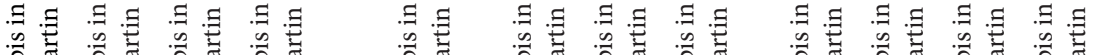

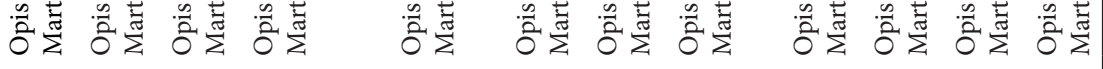

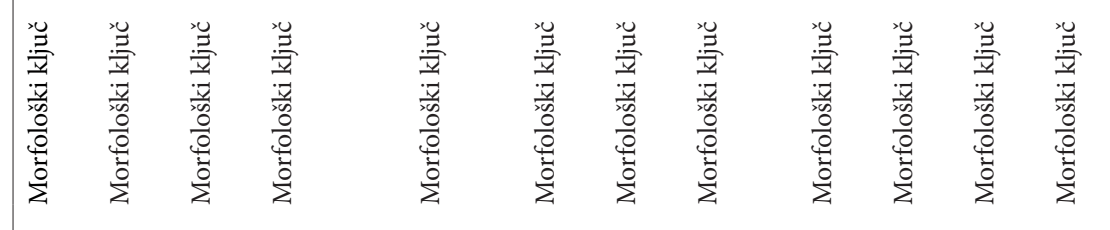

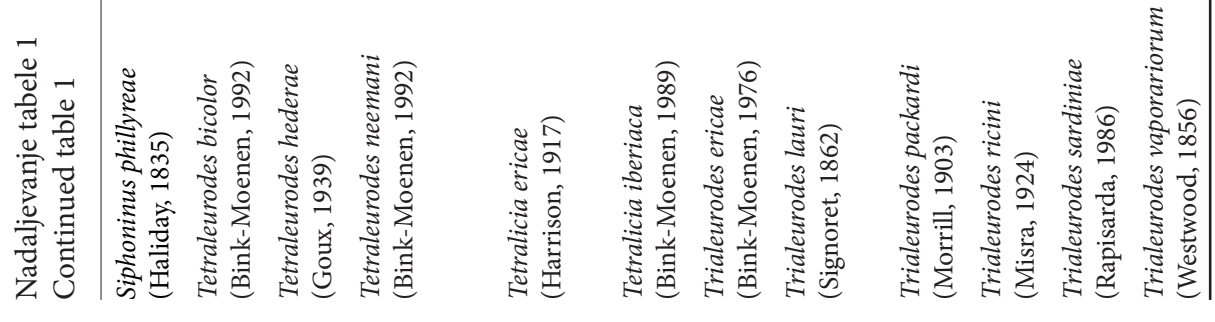


vhodne RGB fotografije, v drugem koraku se ustvarijo zelene slikovne točke $\mathrm{v}$ procesu segmentacije fotografije, tretji korak je statistična obdelava uporabnih segmentov fotografije in v četrtem koraku izbrani deli fotografije preidejo $\mathrm{v}$ proces klasifikacije. Uspešnost algoritmov pri detekciji rastlinskih bolezni je kar 94 $\%$. Posebna pozornost je namenjena tudi prepoznavanju škodljivcev za namen determinacije in biotičnega varstva rastlin. Metoda temelji na barvnem hologramu, prepoznavanju robov in ekstrakciji pomembnih elementov (Uma Rani in Amsini, 2016).

\subsubsection{Predpriprava fotografije za obdelavo}

V sklopu priprave fotografije je potrebno posneti fotografijo poškodovanega lista rastline ali škodljivca in jo nato prenesti $\mathrm{v}$ program za predpripravo (slika 2), segmentacijo in SVM (angl. support vector machines) klasifikacijo. Raztezanje kontrasta (slika 3) je tehnika, ki izboljša kontrast vhodne fotografije, saj je potrebno pred izvedbo k-algoritma izboljšati kvaliteto fotografije (Uma Rani in Amsini, 2016).

\subsubsection{K-vrednost grozdenje}

Segmentacija fotografije je klasifikacija območij na fotografiji v posamezne skupine. K-vrednostni algoritem omogoča grozdenje podatkov in segmentiranje primernih objektov od ozadja. K-vrednost grozdenje je metoda vektorske kvantizacije. Grozd je zbirka podobnih objektov, ki se razlikujejo od grozda ostalih objektov. Grozdenje (slika 4) je posledica

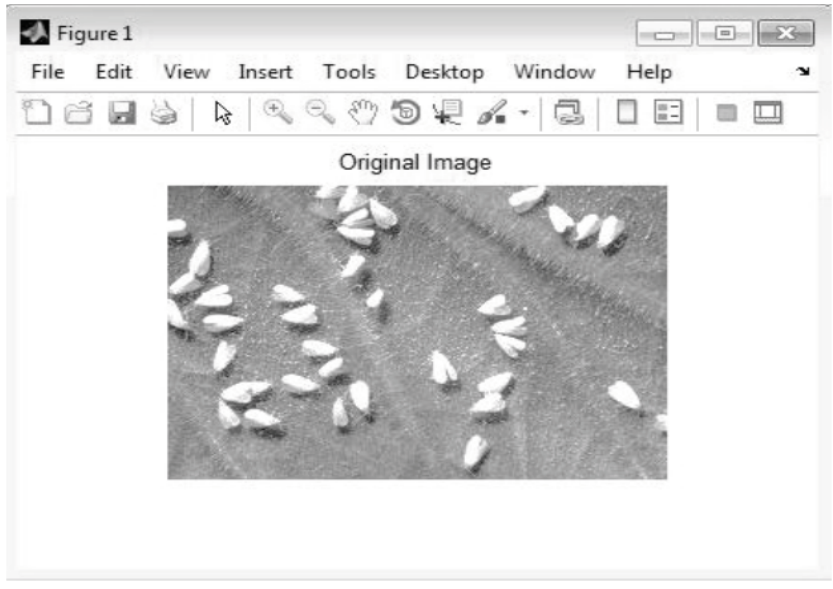

Slika 2: Vhodna fotografija škodljivca (Uma Rani in Amsini, 2016).

Figure 2: A sample leaf image with whiteflies (Uma Rani in Amsini, 2016).

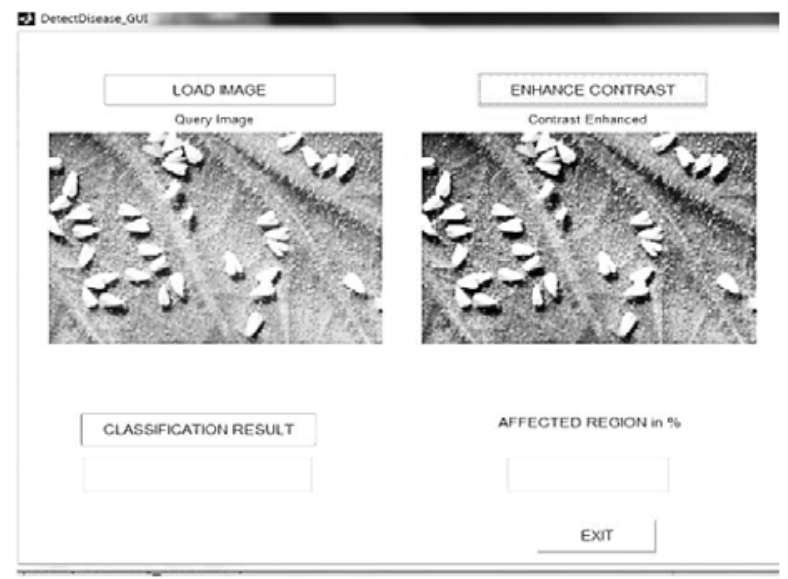

Slika 3: Raztezanje kontrasta (Uma Rani in Amsini, 2016)

Figure 3: The leaf image after preprocessing (Uma Rani in Amsini, 2016). 


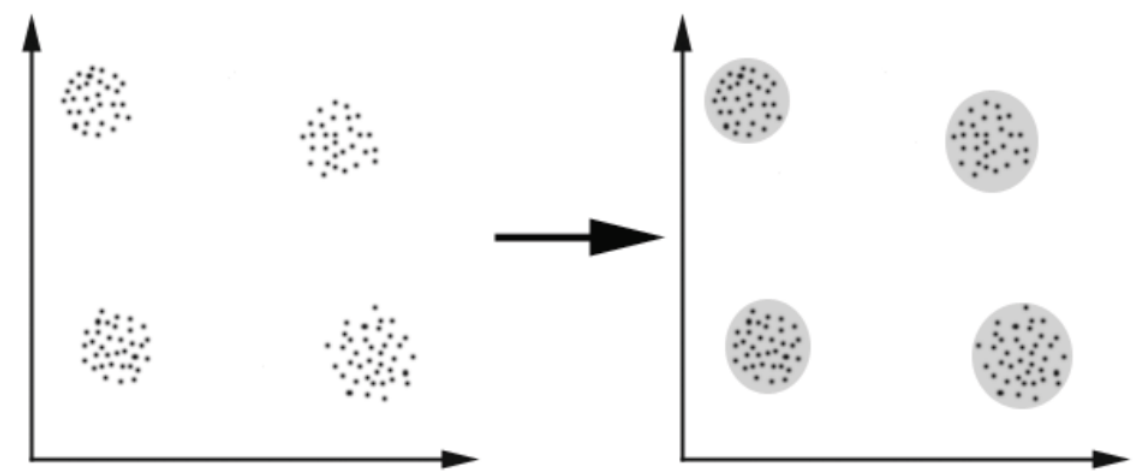

Slika 4: Grozdenje medsebojno podobnih območij (Uma Rani in Amsini, 2016).

Figure 4: Clustering process diagram (Uma Rani in Amsini, 2016).

\begin{tabular}{|c|c|c|}
\hline & Positive(+1) & Negative(-1) \\
\hline Positive & True positive(TP) & False negative(FN) \\
\hline Negative & False positive(FP) & True negative(TN) \\
\hline
\end{tabular}

Slika 5: Binarna klasifikacija pridobljenih podatkov (Uma Rani in Amsini, 2016).

Figure 5: SVM binary classification (Uma Rani in Amsini, 2016).

statistične analize, prepoznavanja in obdelave vhodne fotografije ter medsebojno podobnih območij. Zaradi enostavnosti in učinkovitosti je ena izmed prvih tehnik segmentacije fotografij. Za takšno obliko analize je potreben program Mat Lab. Kvaliteta analize se odraža v večjem številu grozdov. V kolikor je število grozdov manjše, je kvaliteta analize vprašljiva (Uma Rani in Amsini, 2016).

\subsubsection{SVM klasifikator}

SVM (angl. support vector machine) je močno orodje v binarni klasifikaciji, ki hitro generira pridobljene podatke. Regresijske in klasifikacijske analize so osnova za SVM klasifikator. Ocena klasifikatorja temelji na vhodnem območju, ki se generira kot "pra- vilno« in »nepravilno«(slika 5), kar predstavlja binarno klasifikacijo fotografije (Uma Rani in Amsini, 2016).

\subsubsection{Natančnost ocene poškodovanega območja in parametri ocene}

Škodljivci, kot so ščitkarji, so manjših velikosti in napadajo liste rastlin. Samice izležejo do 150 jajčec, okoli 25 na dan. Življenjski krog ščitkarjev traja 21-36 dni. Regija poškodovanega in napadenega lista ali škodljivca se tako izračuna s SVM klasifikatorjem. Parametri k-vrednosti klasifikacijske metode so povprečje, standardna deviacija, entropija, RMS, varianca, gladkost podlage, kontrast, korelacija in homogenost vzorca (Uma Rani in Amsini, 2016). 


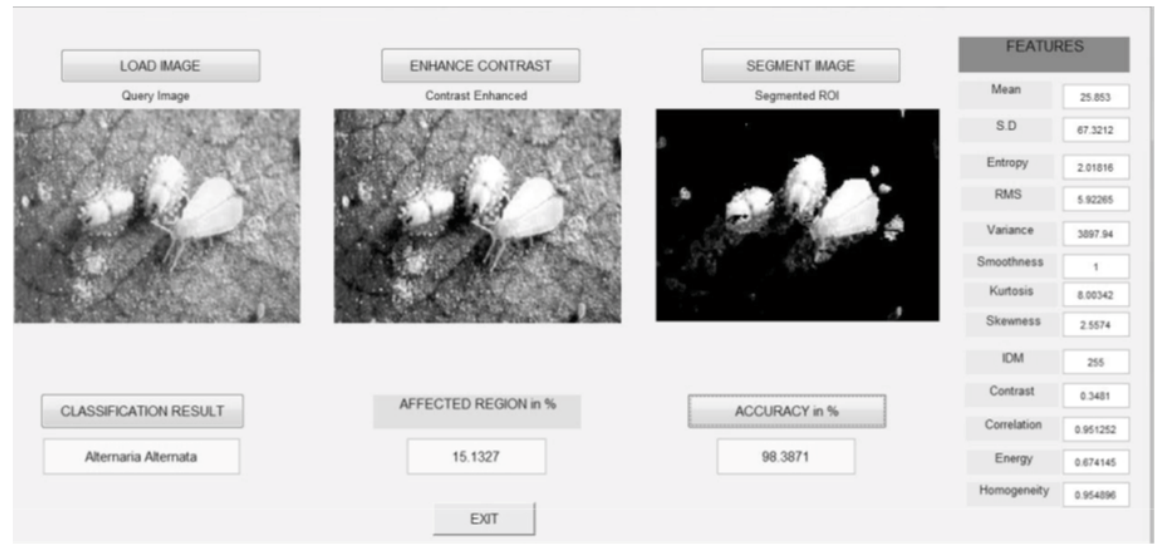

Slika 6: Segmentacija škodljivca (Uma Rani in Amsini, 2016).

Figure 6: Segmentation of leaf pest (Uma Rani in Amsini, 2016).

\subsubsection{Rezultati}

Vhodna fotografija nastane $\mathrm{z}$ digitalnim fotoaparatom in je popolnoma neobdelana, zato jo je potrebno pripraviti na statistično analizo $s$ k-povprečjem barv in tehniko segmentacije. Nato lahko s SVM klasifikatorjem natančno izračunamo območje poškodovane regije ali škodljivca (slika 6) (Uma Rani in Amsini, 2016).

\subsection{MOLEKULARNA IDENTIFIKACIJA}

Zaradi dolgotrajnega in omejenega morfološkega določanja vrst ščitkarjev, kjer je za le-to ustrezna le stopnja puparija, so se razvile številne molekularne metode, kjer vzorec predstavlja odrasla žuželka ščitkarja. Identifikacija odraslih osebkov ščitkarjev je zapletena, pri čemer pa je omejena na gostiteljske rastline določene vrste, kar pogosto privede do zapletov pri prepoznavanju novih vrst. Za določanje vrst ščitkarjev je v uporabi analizna metoda na osnovi mitohondrijske citokrom oksidaze I (COI). Gen COI je eden izmed trinajstih genov, ki kodirajo proteine znotraj mitohondrijskega genoma. Gradi ga 512 aminokislin, ki so urejene iz konca $5^{\prime}$ tRNA-Trp-Tyr-Cys in na $3^{\prime}$ koncu tRNK-Cys (Hajibabaei in sod., 2007). Po sekvenciranju pridobljene rezultate vnesemo $v$ bazo podatkov GenBank, EMBL ali BOLD. Informacije iz posamezne baze so omogočile določitev vrste ščitkarja (Ovalle in sod., 2014). Na osnovi pridobljenih sekvenc in znanih aminokislinskih zaporedij je mogoče izdelati taksonomsko drevo, iz katerega je razvidna filogenetska povezava posameznih vrst ščitkarjev. Izdelano taksonomsko drevo je pogosto $\mathrm{v}$ veliko pomoč morfološki determinaciji posamezne vrste (Ovalle in sod., 2014).
Pri nekaterih vrstah ščitkarjev je mogoče določiti tudi posamezne biotipe. Tobakov ščitkar je vrsta ščitkarja, za katero velja izrazita genetska raznolikost, ki pa je ni moč zaznati morfološko, zato je determinacija posameznega biotipa mogoča le z molekularno tehnologijo. Genetski polimorfizem so sprva proučevali na omenjeni vrsti na osnovi vzorcev esteraz (Brown in sod., 1995). Ta metoda ima še vedno veliko vrednost pri določanju biotipov, predvsem zaradi zgodovinskih povezav. Z namenom prepoznavanja posameznih biotipov vrste tobakov ščitkar so v uporabi številni biokemijski in molekularni markerji (Frohlich in sod., 1999), ki omogočajo prepoznavo polimorfizma znotraj vrste. Med številnimi nekodirajočimi in kodirajočimi regijami, ki predstavljajo molekulske markerje, ima $m t C O I$ sekvenca največjo variabilnost pri posamezni vrsti, kar doprinese največje število informacij o raznolikosti posameznih biotipov znotraj vrste. $\mathrm{Z}$ napredkom molekularne tehnologije je $\mathrm{v}$ zadnjem obdobju v uporabi PCR v realnem času, to je implementacija $5^{\prime}$ nukleaznega fluorogenega testa, znanega kot TaqMan PCR v realnem času. TaqMan analiza temelji na sekvenci specifično označene oligonukleotidne sonde, ki se pripne na tarčno DNK znanih začetnih oligonukleotidov. Metoda TaqMan temelji na hidrolizi sond. Pri podaljševanju verige se sonda odcepi od tarče, poročevalec se loči od dušilca, pri čemer nastane fluorescenca, ki se za vsak cikel prikazuje na zaslonu naprave PCR v realnem času. Fluorescenčni signal je enak količini proučevanega produkta v vzorcu. Prednosti uporabe TaqMan metode in analize PCR v realnem času je izredna občutliivost, natančnost, specifičnost in uporaba splošnih generičnih nastavitev za posamezni cikel. Rezultati so grafični prikaz občutljive detekcije biotipov znotraj vrste tobakov ščitkar (slika 7) (Papayiannis in sod., 2009). 


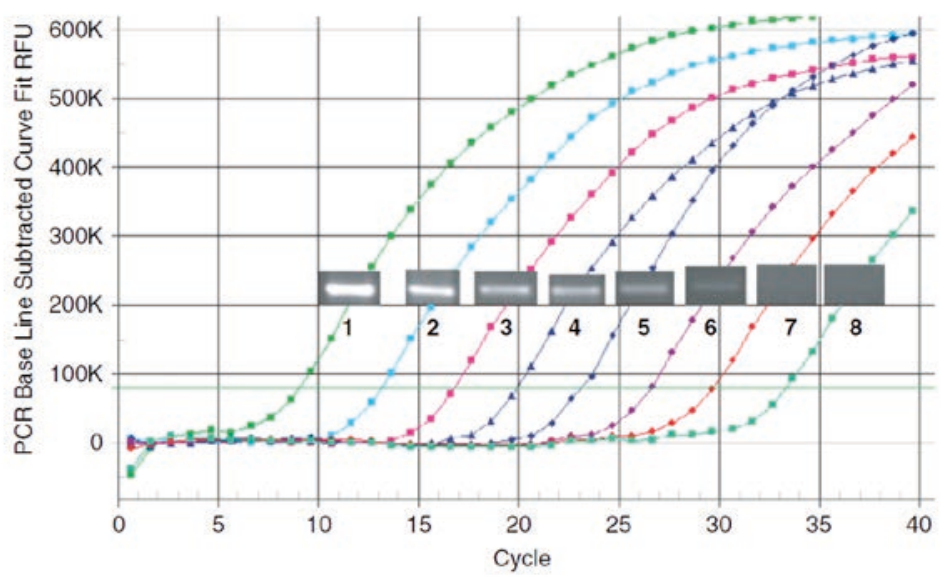

Slika 7: Prikaz občutljivosti metode PCR v realnem času glede na RT-PCR za biotip B vrste tobakov ščitkar (Papayiannis in sod., 2009).

Figure 7: Sensitivity of the qPCR assay for B. tabaci biotype B detection compared with conventional PCR (Papayiannis in sod., 2009).

\section{SKLEPI}

V primerjavi z listnimi ušmi (Aphidoidea) in celotnim razredom žuželk, so ščitkarji vrstno manj pestra skupina. Eden izmed razlogov je kompleksna in nenatančna morfološka determinacija, pomanjkljivi in poddružinsko specifični določevalni ključi ter problematična zgodovina taksonomije. Pomanjkljiva sistematika in taksonomija temelji predvsem na morfološki determinaciji ščitkarjev le na podlagi značilnosti puparija, ki ima velik potencial filogenetske variabilnosti tudi znotraj vrst. Prav to je vodilo $\mathrm{v}$ večkratno opisovanje istih vrst (Martin in Mound, 2007). Zaradi omejene in otežene morfološke determinacije so se razvile številne moderne tehnike determinacije ščitkarjev, med katerimi sta najpogosteje $\mathrm{v}$ uporabi programska oprema Proposed system in molekularne analize specifičnih genov ter PCR v realnem času. Računalniško procesiranje fotografije je pomembna tehnika zgodnjega odkrivanja in prepoznavanja škodljivcev na rastlinah in pripomore $\mathrm{k}$ nadaljnjim ukrepom varstva rastlin (Uma Rani in Amsini, 2016). COI sekvenčna analiza je natančna in učinkovita metoda vrstne identifikacije ščitkarjev. Molekularne metode so pomemben element hitrega in natančnega določanja vrste ter uporabne pri identifikaciji domačih vrst in napovedi invazivnih vrst po vdoru na novo območje. Molekularna diagnostika omogoča identifikacijo intraspecifičnih sprememb znotraj vrste, spremljanje širjenja posamezne vrste, napoved pojava naravnih sovražnikov ščitkarjev in s tem načrtovanje biotičnega zatiranja tega škodljivca (Ovalle in sod., 2014). Primer kriptične vrste je $B$. tabaci, saj bioloških in genetskih variacij te vrste ni mogoče morfološko ločiti med seboj. Pri tem imajo pomembno vlogo molekularne metode, ki omogočajo določitev posameznih markerjev, na podlagi katerih lahko razlikujemo posamezne biotipe in polimorfizem vrste. Med številnimi nekodirajočimi in kodirajočimi markerji, se največja variabilnost kaže znotraj gena $m t C O I$, kar doprinese veliko količino informacij o razlikah znotraj vrste in posameznega biotipa (Papayiannis in sod., 2009). Pomembnost in natančnost molekularnih pristopov se izraža tudi pri določanju seznama karantenskih organizmov. Zaradi zgolj morfološke determinacije, ščitkarji pogosto niso uvrščeni na seznam karantenskih organizmov, saj je glede na določitev na območju zastopana le ena, neinvazivna vrsta. Molekularne metode so pogosto potrdile zastopanost dveh vrst na določenem območju, kjer je bila morfološko določena le ena vrsta, kar je omogočilo prepoznavanje in uvrstitev invazivnih vrst na seznam karantenskih organizmov (Malumphy in sod., 2009).

\section{VIRI}

Andreason, S. A., Arif, M., Brown, J. K., Ochoa-Corona, F., Fletcher, J., Wayadande, A. (2017). Single-target and multiplex discrimination of whiteflies (Hemiptera: Aleyrodidae) Bemisia tabaci and Trialeurodes vaporariorum with modified priming oligonucleotidet. Journal of Economic Entomology, 1-10. https://doi.org/10.1093/jee/tox125

Bink-Moenen, R. M. \& Gerling, D. (1990). Aleyrodidae of Israel. Bollettino del Laboratorio di zoologia generale e agraria della R. Scuola superiore d'agricoltura in Portici (Filippo Silvestri), 47, 3-39.

Brown, J. K., Coats, S. A., Bedford, I. D., Markham, P. G., Bird, J., Frohlich, D. R. (1995). Characterization and distribution 
of esterase electromorphs in the whitefly Bemisia tabaci (Genn.) (Homoptera: Aleyrodidae). Biochemical Genetics, 33, 205-214. https://doi.org/10.1007/BF02401851

Botha, J., Hardie, D., Power, G. (2000). Spiraling whitefly Aleurodicus dispersus: Exotic threat to Western Australia. Fact Sheet.

Brown, W. M., George, M., Wilson, A. C. (1979). Rapid evolution of animal mitochondrial DNA. Proceedings of the National Academy of Sciences, 76, 1967-1971. https://doi. org/10.1073/pnas.76.4.1967

Byrne, D. N.\& Bellows, Jr. T. S. (1991). Whitefly biology. Annual Review of Entomology, 36, 431-457. https://doi. org/10.1146/annurev.en.36.010191.002243

Caldeira, R. L., Carvalho, O. S., Mendonca, C. L., Graeff-Teixeira, C., Silva, M. C. F., Ben, R., Maurer, R., Lima, W. S., Lenzi, H. L. (2003). Molecular differentiation of Angiostrongylus costaricensis, A. cantonensis, and A. vasorum by polymerase chain reaction-restriction fragment length polymorphism. Memorias do Instituto Oswaldo Cruz, 98, 1039-1043. https://doi.org/10.1590/S0074-02762003000800011

Calvert, L. A., Cuervo, M., Arroyave, J. A., Constantino, L. M., Bellotti, A., Frohlich, D. (2001). Morphological and mitochondrial DNA marker analyses of whiteflies (Homoptera: Aleyrodidae) colonizing cassava and beans in Colombia. Annals of the Entomological Society of America, 94, 512-519. https://doi.org/10.1603/0013-8746(2001)094[0512:MAMD MA]2.0.CO;2

Campbell, B. C., Duffus, J. E., Baumann, P., Bartlett, A. C., Gawel, N. J., Perring, T. M., Farrar, C. A., Cooper, A. D., Bellows, Jr. T. S., Rodriguez, R. J. (1993). Determining whitefly species. Science, 261, 1333-1335. https://doi.org/10.1603/00138746(2001)094[0512:MAMDMA]2.0.CO;2

Frohlich, D. R., Torres-Jerez, I., Bedford, I. D., Markham, P. G., Brown, J. K. (1999). A phylogeographic analysis of the Bemisia tabaci species complex based on mitochondrical DNA markers. Molecular Ecology, 8, 1683-1691. https:// doi.org/10.1046/j.1365-294x.1999.00754.x

Francis, A. W., Stocks, I., Smith, T. R., Boughton, A. J., Mannion, C. M., Osborne, L. S. (2016). Host plants and natural enemies of rugose spiraling whitefly (Hemiptera: Aleyrodidae) in Florida. Florida Entomologist, 99(1), 150-153. https://doi.org/10.1653/024.099.0134

Ghahari, H., Abd-Rabou, S., Zahradnik, J., Ostovan, H. (2009). Annotated catalogue of whiteflies (Hemiptera: Sternorrhyncha: Aleyrodidae) from Arasbaran, Northwestern Iran. Journal of Entomology and Nematology, 1, 7-18.

Gill, R. (1990). The morphology of whiteflies. Intercept LTD, United Kingdom, 13-46.

Guershon, M. \& Gerling, D. (2001). Effect of foliar tomentosity on phenotypic plasticity in Bemisia tabaci (Hom., Aleyrodidae). Journal of Applied Entomology, 125, 449-453. https:// doi.org/10.1046/j.1439-0418.2001.00571.x

Habib, A., Farag, F. A. (1970). Studies on nine common aleurodids of Egypt. Bulletin de la Société Entomologique d'Egypte, $54,1-41$.

Hajibabaei, M., Singer, G. A. C., Hebert, P. D. N., Hickey, D. A. (2007). DNA barcoding: how it complements taxonomy, molecular phylogenetics and population genetics.
Trends in Genetics, 23, 167-172. https://doi.org/10.1016/j. tig.2007.02.001

Hebert, P. D. N., Cywinska, A., Ball, S. L., de Waard, J. R. (2003). Biological identifications through DNA barcodes. Proceedings of the Royal Society B: Biological Sciences, 270, 313-321. https://doi.org/10.1098/rspb.2002.2218

Hebert, P. D., Ratnasingham, S., de Waard, J. R. (2003). Barcoding animal life: cytochrome $\mathrm{c}$ oxidase subunit 1 divergences among closely related species. Proceedings of the Royal Society B: Biological Sciences, 270, 96-99. https://doi. org/10.1098/rsbl.2003.0025

Hoddle, M. S. (2004). The biology and management of silverleaf whitefly, Bemisia argentifolii Bellows and Perring (Homoptera: Aleyrodidae) on greenhouse grown ornamentals. Applied Biological Control Research.

Hodges, G. S. \& Evans, G. A. (2005). An identification guide to the whiteflies (Hemiptera: Aleyrodidae) of southeastern united states. Florida Entomologist, 88, 518-534. https://doi. org/10.1653/0015-4040(2005)88[518:AIGTTW]2.0.CO;2

Kress, W. J. \& Erickson, D. L. (2008). DNA barcodes: genes, genomics, and bioinformatics. Proceedings of the $\mathrm{Na}$ tional Academy of Sciences, 105, 2761-2762. https://doi. org/10.1073/pnas.0800476105

Kwong, S., Srivathsan, A., Meier, R. (2012). An update on DNA barcoding: low species coverage and numerous unidentified sequences. Cladistics, 28, 639-644. https://doi. org/10.1111/j.1096-0031.2012.00408.x

Lunt, D. H., Zhang, D. X., Szymura, J. M., Hewltt, O. M. (1996). The insect cytochrome oxidase I gene: evolutionary patterns and conserved primers for phylogenetic studies. Insect Molecular Biology, 5, 153-165. https://doi. org/10.1111/j.1365-2583.1996.tb00049.x

Malumphy, C., Walsh, K., Suarez, M. B., Collins, D. W., Boonham, N. (2009). Morphological and molecular identification of all developmental stages of four whitefly species (Hemiptera:Aleyrodidae) commonly intercepted in quarantine. Zootaxa, 2118, 1-29. https://doi.org/10.11646/ zootaxa.2118.1.1

Martin, J. H. (1985). The whitefly of New Guinea (Homoptera: Aleyrodidae). Bulletin of the British Museum (Entomology), 50(3), 303-351.

Martin, J. H. (1987). An identification guide to common whitefly pest species of the world (Homoptera, Aleyrodidae). Tropical Pest Management, 33(4), 298-322. https://doi. org/10.1080/09670878709371174

Martin, J. H. (1999). The whitefly fauna of Australia (Sternorrhyncha: Aleyrodidae). A taxonomic account and identification guide. Technical Paper, 38, 197.

Martin, J. H. \& Mound, L. A. (2007). An annotated check list of the world's whiteflies (Insecta: Hemiptera: Aleyrodidae). Zootaxa, 1-84. https://doi.org/10.11646/zootaxa.1492.1.1

Martin, J., Mifsud, D., Rapisarda, C. (2000). The whiteflies (Hemiptera: Aleyrodidae) of Europe and the Mediterranean basin. Bulletin of Entomological Research, 90, 407-448. https://doi.org/10.1017/S0007485300000547

Mifsud, D. (1995). Whiteflies of the Maltese Islands (Homoptera, Aleyrodidae). Central Mediterranean Naturalist, 2(3), 61-78.

Milevoj, L. (2003). Prsokljunci - Sternorryncha. V: Živalstvo 
Slovenije. Sket B., Gogala M., Kuštor V. (ur.). Ljubljana. Tehniška založba Slovenije. 355-361.

Mound, L. A. (1966). A revision of the British Aleyrodidae (Hemiptera: Homoptera). Bulletin of the British Museum (National History), 17(9), 397-428. https://doi.org/10.5962/bhl. part.14809

Oliveira, M. R. Vd., Tigano, M. S., Aljanabi, S. (2000). Molecular characterization of whitefly (Bemisia spp.) in Brazil. Pesquisa Agropecuaria Brasileira, 35, 1261-1268. https:// doi.org/10.1590/S0100-204X2000000600023

Ovalle, T. M., Parsa, S., Hernandez, M. P., Becerra Lopez-Lavalle, L. A. (2014). Reliable molecular identification of nine tropical whitefly species. Ecology and Evolution, 4(19), 3778-3787. https://doi.org/10.1002/ece3.1204

Papayiannis, L. C., Brown, J. K., Seraphides, N. A., Hadjistylli, M., Ioannou, N., Katis, N. I. (2009). A real time PCR assay to differentiate the $\mathrm{B}$ and $\mathrm{Q}$ biotypes of the Bemisia tabaci complex in Cyprus. Bulletin of Entomological Research, 1-10. https://doi.org/10.1017/S0007485308006603

Perring, T. M., Farrar, C. A., Bellows, T. S., Cooper, A. D., Rodrigues, R. J. (1993). Evidence for a new species of whitefly: UCR findings and implications. California agriculture, 47(1), 7-8. https://doi.org/10.3733/ca.v047n01p7

Perring, T. M., Stansly, P A., Liu, T. X., Smith, A. H., Andreason, S. A. (2018). Whiteflies: Biology, Ecology, and Management. Sustainable Management of Arthropod Pests of Tomato. Elsevier, 73-110. https://doi.org/10.1016/B978-0-12-8024416.00004-8

Ptaszynska, A. A., Le Ztowski, J., Gnat, S., Malek, W. (2012). Application of COI sequences in studies of phylogenetic relationships among 40 Apionidae species. Journal of Insect Science, 12, 1-14. https://doi.org/10.1673/031.012.1601

Radonjić, S., Hrnčić, S., Malumphy, C. (2014). First record of Aleurocanthus spiniferus (Quaintance) (Hemiptera Aleyrodidae) in Montenegro. Redia, 141-145.

Shatters, R. G., Powell, C. A., Boykin, L. M., Liansheng, H., McKenzie, C. L. (2009). Improved DNA barcoding method for Bemisia tabaci and related Aleyrodidae: development of universal and Bemisia tabaci biotype-specific mitochondrial cytochrome coxidase I polymerase chain reaction primers. Journal of Economic Entomology, 102, 750-758. https://doi.org/10.1603/029.102.0236

Smith, M. A., Bertrand, C., Crosby, K., Eveleigh, E. S., Fernandez-Triana, J., Fisher, B. L., Gibbs, J.,... Zhou, X. (2012). Wolbachia and DNA barcoding insects: patterns, potential, and problems. PLoS One. https://journals.plos.org/plosone/article?id=10.1371/journal.pone.0036514. https://doi. org/10.1371/journal.pone.0036514
Šimala, M., Masten Milek, T., Pintar, M. (2015). The whitefly species (Hemiptera, Aleyrodidae) with dark puparium and pupal case recorded in Croatia. Natura Croatica, 24, 111125. https://doi.org/10.20302/NC.2015.24.6

Takahashi, R. (1952). Aleurotuberculatus and Parabemisia of Japan (Aleyrodidae, Homoptera). Miscellaneous Reports of the Research Institute for Natural Resources, 25, 17-24.

Takahashi, R. (1954). Key to the tribes and genera of Aleyrodidae of Japan, with descriptions of three new genera and one new species (Homoptera). Insecta Matsumurana, 18, 47-53.

Thyssen, P. J., Lessinger, A. C., Azeredo-Espin, A. M., Linhares, A. X. (2005). The value of PCR-RFLP molecular markers for the differentiation of immature stages of two necrophagous flies (Diptera: Calliphoridae) of potential forensic importance. Neotropical Entomology, 34, 777-783.

Trdan, S. (2015). Ščitkarji in prenos virusov s ščitkarji. V: Mavrič Pleško I. (ur.) Prenosi rastlinskih virusov. Ljubljana, Kmetijski inštitut Slovenije. 87-100.

Uma Rani, R. \& Amsini, P. (2016). Pest Identification in Leaf Images using SVM Classifier. International Journal of Computational Intelligence and Informatics, 6, 30-41.

Trdan, S., Kač, M., Bobnar, A., Modic, Š. (2003). Research on the efficacy of the yellow sticky boards to control the cabbage whitefly (Aleyrodes proletella L., Aleyrodidae) on Brussels sprouts. Zbornik Biotehniške fakultete Univerze $v$ Ljubljani, 81(1), 171-177.

Vidigal, T. H., Montresor, L. C., Simpson, A. J., Carvalho, O. S. (2002). Polymerase chain reaction and restriction fragment length polymorphism of cytocrome oxidase subunit I used for differentiation of Brazilian Biomphalaria species intermediate host of Schistosoma mansoni. Memorias do Instituto Oswaldo Cruz, 97, 47-52. https://doi.org/10.1590/ S0074-02762002000900011

Watson, G. W. (2007). Identification of whiteflies (Hemiptera: Aleyrodidae). APEC Re-entry workshop on whiteflies and mealybugs in Malaysia. International Journal of Advanced Research.

Watson, G. W. \& Chandler, L. R. (1999). Identification of Mealybugs important in the Carribean Region with notes on preparation of whitefly pupae for identification. Commonwealth Science and CAB International, 40.

Wilkey, R. F. (1962). A simplified technique for clearing, staining and permanently mounting small arthropods. Annals of the Entomological Society of America, 55, 606. https://doi. org/10.1093/aesa/55.5.606 